\title{
On the luminous intensities of the radiations emitted
}

\section{Prof. J. Violle}

To cite this article: Prof. J. Violle (1882) On the luminous intensities of the radiations emitted, Philosophical Magazine Series 5, 13:79, 147-149, DOI: 10.1080/14786448208627158

To link to this article: http://dx.doi.org/10.1080/14786448208627158

曲 Published online: 28 Apr 2009.

Submit your article to this journal ¿

Џ Article views: 2

Q View related articles $\sqsubset$ 
lying conformably on the Upper Silnrian Beds, as seen in the coast of the Dingle promontory and overlain unconformably by either Old Red Sandstone or Lower Carboniferous beds, 10,000 to 12,000 feet.

North.-“" The Fintona Beds," occupying large tracts of Londonderry, Monaghan, and Tyrone, resting unconformably on the Lower Silurian beds of Pomeroy, and overlain unconformably by the Old Red Sandstone or Lower Carboniferous beds, 5000 to 6000 feet in thickness.

\section{SCOTLAND.}

Beds of the so-called "Lower Old Red Sandstone," with fish and crustaceans, included in Professor Geikie's "Lake Orcadie, Lake Caledonia, and Lake Cheviot," underlying unconformably the Old Red Sandstone and Lower Calciferous Sandstone, and resting unconformably on older crystalline rocks. Thickness in Caithness about 16,200 feet.

The author considered that all these beds were representative of one another in time, deposited under lacustrine or estuarine conditions, and, as their name indicated, forming a great group intermediate between the Silurian on the one hand and the Devonian on the other. He also submitted that their importance, as indicated by their great development in Ireland and Scotland, entitled them to a distinctive name such as that proposed.

\section{Intelligence and Miscellaneous Articles.}

ON THE LUMINOUS INTENSITIES OF THE RADIATIONS EMITTED

BY INCANDESCENT PLATINUM. RY PROF. J. VIOLLE.

T HAVE measured at different temperatures, and for various radiations, the light-intensities of incandescent platinum.

I have selected as temperatures some of the melting-points which I previously determined in degrees of the air-thermometer, and which I here repeat (correcting the melting-point of gold, which was set down by mistake at $1035^{\circ}$ ) :-

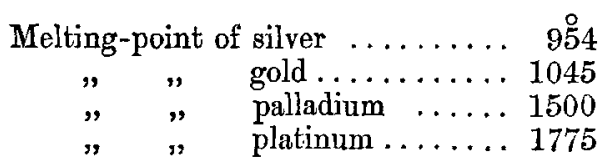

In order to get some platinum, for example, at $1045^{\circ}$, a button of platinum of about 200 grams weight was put into a crucible of unglazed porcelain, which was introduced into a second crucible, made of fireclay, and already containing at its lower part 500 grams of gold. The whole was placed in a large vertical Perrot furnace traversed along its axis by a long fireclay tube, through which the surface of the platinum could be seen. It was heated up to the fusion of the gold; the arrival gas-cock was then, to a slight extent, 
partially closed, so as to induce a commencement of solidification ; the cock was again touched; and by thus modifying the arrival of the gas, it was kept, without too much difficulty, just at the point of fusion. The great mass of the furnace secures a sufficiently extensive constant thermal field, and permits its constancy to be easily maintained.

The operation was precisely the same for bringing the platinum to and keeping it at $954^{\circ}$, the outer crucible containing silver instead of gold.

It is rather more difficult to accomplish the operation in the palladium bath; it can, however, be done by feeding the furnace with a Schlcesing blowpipe and protecting the crucibles by graphite casings. Palladium can also be made use of more simply, even at its melting-point, by employing Deville and Debray's furnace and blowpipe.

For the photometric measurements I employed successively the two methods by which luminous intensities are usually measuredthe comparison of two contiguous luminous fields, and the extinction of the isochromatic lines called forth by a sensitive polariscope. $I$ used for this purpose the Gouy spectrophotometer and a Trannin spectrophotometer, suitably modified for the present use; and although each of these apparatus suits better than the other in certain cases, I thus obtained a valuable control of the results. The source taken as the term of comparison, in all the experimente, was the Carcel standard lamp burning 42 grams of oil per hour.

The following Table contains the results thus obtained, plus those of a series made at $775^{\circ}$ (temperature measured by the calorimetric method).

\begin{tabular}{|c|c|c|c|c|}
\hline \multirow{3}{*}{$\begin{array}{l}\text { Temperatures. } \\
775^{\circ} \ldots\end{array}$} & \multicolumn{4}{|c|}{ Intensities. } \\
\hline & $\lambda=656$. & $\lambda=589 \cdot 2$. & $\begin{array}{c}\lambda=535 . \\
(\mathrm{E}=527)\end{array}$ & $\begin{aligned} \lambda & =482 . \\
(\mathrm{F} & =486)\end{aligned}$ \\
\hline & 0.00300 & 0.00060 & 0.00030 & \\
\hline 954 & 0.01544 & $2 \cdot 01105$ & $0.00715(?)$ & \\
\hline 1045 & $0 \cdot 0505$ & 0.0402 & 0.0265 & 0.0162 \\
\hline 1500 & 2.371 & $2 \cdot 417$ & $\mathbf{2} \cdot 198$ & $1 \cdot 894$ \\
\hline 1775 & $7 \cdot 829$ & 8.932 & $9 \cdot 759$ & $12 \cdot 16$ \\
\hline
\end{tabular}

If, then, the luminous intensity of incandescent platinum at $954^{\circ}, 1045^{\circ}$, and $1500^{\circ}$, in the various simple radiations, be successively taken for the unit, we get for the relative intensities :-

$$
\begin{array}{rrrrrrrrrrrrr}
775 & \ldots & 0 \cdot 19 & \ldots & \ldots & 0.05 & \ldots & \ldots & 0.04 & & & & \\
954 & \ldots & 1 & \ldots & \ldots & 1 & \ldots & \ldots & 1 & & & & \\
1045 & \ldots & 3 \cdot 27 & 1 & \ldots & 3 \cdot 64 & 1 & \ldots & 3 \cdot 71 & 1 & \ldots & 1 & \\
1500 & \ldots & 154 & 47 & 1 & 219 & 60 & 1 & 307 & 83 & 1 & 117 & 1 \\
1775 & \ldots & 507 & 155 & 3 \cdot 30 & 809 & 222 & 3 \cdot 70 & 1365 & 368 & 4 \cdot 44 & 752 & 6 \cdot 42
\end{array}
$$

Various consequences follow from these numbers, both for the 
law of radiation at high temperatures, and in regard to the measurement of those high temperatures by photometry. I shall shortly resume these two important questions, at present confining myself to indicating the formula

$$
\mathrm{I}=m \mathrm{~T}^{\mathbf{3}}\left(1+\epsilon \alpha^{-T}\right)^{\mathbf{T}}
$$

as well representing the results. $I$ is the intensity of a simple radiation; $\mathrm{T}$, the absolute temperature; $m, \mathbf{\epsilon}$, and $\alpha$, constants which will have to be determined.-Comptes Rendus de l'Académie des Sciences, t. xcii. p. 866 (1881).

\section{AN APPLICATION OF ACCIDENTAL IMAGES. (SECOND NOTE.) BY J. PLATEAU.}

In my first Note* I showed that the distance to which we refer the moon in the sky can be pretty exactly estimated by projecting upon a wall the dark accidental image which succeeds the contemplation of the moon itself, then receding from or approaching towards the wall till the diameter of the image is judged to be equal to that of the celestial object, and, lastly, measuring the distance at which the observer is from the wall when this condition appears to be fulfilled. I said then that one of my sons had by this means obtained about 51 metres for the distance in question. As this value seemed very small, I have more recently induced my son to make a control experiment, although with less precision : he sought a position, in front of the wall, such that the diameter of the dark image appeared to him as exactly as possible half of that of the moon; and this required him to be distant from the wall not more than 23.5 metres. Now, in virtue of the known proportionality between the diameter of the accidental image and the distance to which it is projected, double the above quantity, viz. 47 metres, consequently represented approximately the distance at which my son instinctively placed the moon; and it will be seen that this latter distance, though not coinciding with the 51 metres of the previous experiment less subject to error, is nevertheless of the same order.

M. l'abbé Thirion, Professor at the Collège de la Paix at Namur, has since published ${ }^{t}$ an estimate at which he arrived by a quite different procedure. He assembled twelve of his pupils, and asked each of them to trace on a black board a circumference of the size he saw the moon in the sky. These twelve circumferences were very unequal; the smallest was only 19 centim. in diameter, while

* Bull. Acad. Roy. Belg. [2] xlix. 1880, p. 316; Phil. Mag. August 1880 , p. 134.

$\dagger$ La Lune-les préjugés et les illusions: Bruxelles, 1881.

Phil. Mag. S. 5. Vol. 13. No. 79. Feb. 1882. 